
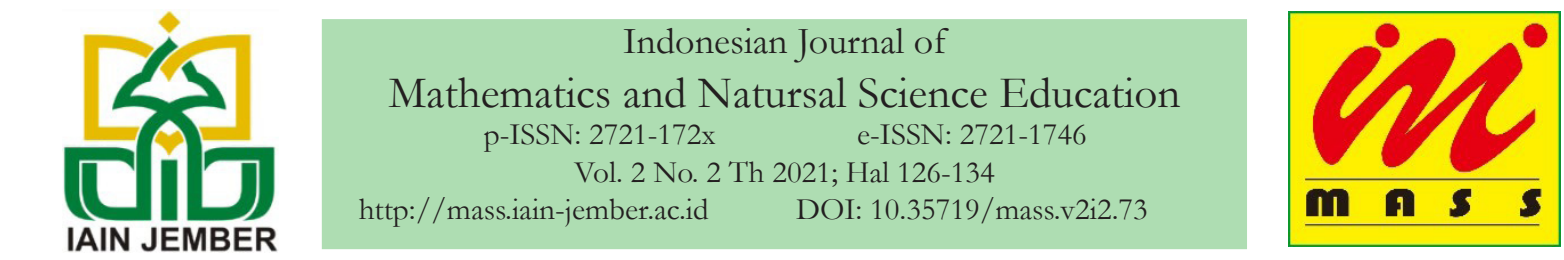

\title{
Pengembagan Modul Pembelajaran IPA Berbasis Socio Scientific Issues (SSI) Materi Sistem Pernapasan Manusia untuk Siswa Kelas VIII SMP
}

\author{
Darmawan Setiadi ${ }^{1}$, Erik Perdana Putra ${ }^{1}$ * \\ ${ }^{1}$ Prodi Pendidikan IPA, IAIN Bengkulu, Bengkulu \\ "E-mail: erik.perdana@iainbengkulu.ac.id
}

\begin{abstract}
Abstrak
Penelitian ini bertujuan untuk mengembangkan modul pembelajaran IPA berbasis socio scientific issues (SSI) pada materi sistem pernapasan manusia untuk siswa kelas VIII SMP yang layak dan praktis digunakan setelah divalidasi oleh beberapa ahli dan responden (guru dan siswa). Metode penelitian yang digunakan model pengembangan Borg and Gall yang terdiri dari 10 tahapan, namun dalam penelitian ini disederhanakan menjadi 8 tahapan karena keterbatasan waktu dan biaya. Langkah penelitian tersebut meliputi produksi masal potensi dan masalah, pengumpulan informasi, desain produk, validasi desain, revisi desain, uji coba produk kelompok terbatas, revisi produk, produk akhirSubjek penelitian ini adalah 3 dosen yang terdiri atas dosen ahli materi, ahli bahasa, ahli media, serta 10 orang siswa kelas VIII SMP Negeri 11 Bengkulu Tengah beserta 1 orang guru IPA kelas VIII. Data hasil analisis angket, modul pembelajaran IPA berbasis berbasis socio scientific issues (SSI) materi sistem pernapasan manusia dinyatakan sangat layak dengan presentase ahli bahasa 94,66 \% (sangat layak), ahli materi 91,7\% (sangat layak), dan ahli media/desain 97,7\% (sangat layak). Respons siswa terhadap bahan ajar modul yakni 82,87 $\%$ (sangat praktis), dan hasil responden guru sebesar 73,71 \% (praktis). Berdasarkan hasil data tersebut dapat disimpulkan bahwa modul sangat layak dan praktis digunakan sebagai bahan ajar.
\end{abstract}

Kata kunci: Etnomatematika, LKS, Pengembangan

\section{PENDAHULUAN}

Segala sesuatu yang dapat membawa informasi dan pengetahuan ke dalam interaksi berkelanjutan antara pendidik dan siswa disebut sebagai pembelajaran. Individu terlibat dalam pembelajaran untuk mencapai modifikasi perilaku baru secara keseluruhan sebagai konsekuensi dari pengalaman mereka sendiri dalam kontak dengan lingkungan mereka (Dewi dkk, 2018).

Bahan ajar mengacu pada seperangkat sumber belajar yang digunakan untuk memenuhi persyaratan kompetensi dan keterampilan dasar yang telah ditentukan sebelumnya (Nurdyansyah, 2018:2). Materi pendidikan disengaja, menyiratkan bahwa mereka diatur untuk membuatnya lebih mudah bagi siswa untuk belajar. Bahan ajar dapat dirangkai menjadi dua kelompok penting, yaitu jenis bahan ajar cetak dan non cetak. Jenis bahan ajar cetak yang dimaksud adalah freebees, Lembar Kerja Siswa (LKS), dan modul. Sedangkan yang dikenang untuk kelas bahan ajar non cetak adalah realia, bahan ajar yang dibuat dari hal yang lugas, bahan ajar yang tenang (pertunjukan), video, suara, dan Overhead Transparencies (OHT) (Sadjati, 2012). Pada penelitian ini akan 
megembangan bahan ajar cetak berupa modul.

Modul adalah sumber daya instruksional mandiri yang terstruktur dengan cara yang logis dan menarik dan mencakup konten materi, teknik, dan penilaian (Ramadhana, 2017:316). Modul pembelajaran berisi petunjuk penggunaan, kompetensi yang akan dicapai, informasi tambahan, latihan, instruksi kerja (bisa berupa LKS), dan penilaian (Auliya dan Nurmawati, 2021). Unsur-unsur tersebut disusun menjadi sebuah modul dengan memperhatikan bahasa modul, materi pelajaran diilustrasikan, sesuai dengan tujuan pembelajaran, dan disesuaikan dengan kemampuan siswa.

Berdasarkan gambaran di atas, dapat disimpulkan bahwa pengajaran harus benar-benar dikoordinasikan untuk menciptakan orang-orang berkualitas yang dapat bersaing, dan memiliki orangorang yang hebat. Untuk mewujudkan hal tersebut, organisasi instruktif (sekolah) diharapkan menyelesaikan latihan pembelajaran. Dalam menyelesaikan siklus belajar, penting untuk memilih materi peragaan yang tepat sesuai dengan keterampilan yang harus dikuasai, salah satu materi peragaan adalah modul. Dalam pembinaan modul, penting untuk fokus pada segmen modul dan standar kesiapan modul. Sebagai tambahan untuk membantu buku dasar, modul tersebut berisi pengenalan materi pembelajaran sesuai kebutuhan siswa.

Setiap materi pembelajaran memiliki tingkat kesulitan yang berubah-ubah. Topik dengan tingkat kesulitan yang semakin tinggi, dan semakin sulit untuk diukur oleh siswa, terutama bahan ajar yang digunakan tidak menarik. Data dalam bahan ajar harus disajikan dalam format yang menarik. Kesulitan siswa dalam memahami materi adalah karena kurangnya minat siswa terhadap materi pembelajaran yang memiliki format yang kurang baik. Format adalah rencana dari komponen-komponenrencanayang terkait ke dalam suatu bidang untuk membentuk suatu tindakan kreatif. Ini juga dapat disebut administrasi struktur dan bidang. Motivasi utama di balik format adalah untuk menunjukkan komponen gambar dan teks agar terbuka dengan cara yang memudahkan pembaca untuk mengenali data yang dimasukkan (Galing W, 2013:7). Sebagai upaya peneliti dalam mengatasi hal tersebut adalah mendesain modul pembelajaran yang memiliki tata letak (layout) tampilan modul yang menarik, agar menumbuhkan keinginan siswa dalam menggunakan bahan ajar modul.

Bahan ajar yang digunakan pengajar dalam penerapan pembelajaran adalah buku cetak, menurut observasi pertama yang dilakukan peneliti di SMP Negeri 11 Bengkulu Tengah pada 25 November 2020. Bentuk fisik dari buku cetak telah lusuh dan beberapa lembar halaman hilang, hal ini karena penggunaan bahan ajar yang digunakan siswa digunakan secara bergantian dari generasi ke generasi. Padahal idealnya siswa akan tertarik menggunakan bahan ajar jika bentuk fisik dari bahan ajar tersebut menarik siswa untuk menggunakannya. Materi yang disampaikan dalam buku cetak, berisi 
intruksi dan materi yang didominasi oleh tulisan dan sedikitnya ilutrasi gambar. Sedangkan pada materi sistem pernapasan manusia terdapat hal-hal yang meliputi konsep, proses, gejala, atau kejadian yang masih abstrak, terdapat hal-hal dalam materi sistem pernapasan manusia yang menyangkut konsep, proses, gejala, atau kejadian yang bersifat masih abstrak. Akan lebih mudah bagi guru untuk menyampaikan topik abstrak agar lebih nyata dengan gambar dan penyajian tata letak (layout) yang menarik pembaca.

Berdasarkan permasalahan diatas dan penelusuran ilmiah yang peneliti lakukan bahwa,desain tata letak (layout) dan kurangnya ilustrasi gambar yang menarik bagi siswa pada buku cetak di sekolah sehingga siswa tidak menyukai materi itu. Padahal sebuah bahan ajar yang menarik akan membuat siswa termotivasi menggunakannya. Kemudian ditemukan tidak adanya edukasi tentang Corona Virus Disease (COVID-19) didalam bahan ajar. Serta belum adanya guru yang mengembangkan bahan ajar modul berbasis Sosio Saintific Issues (SSI).Berdasarkan problema tersebut, Peneliti ingin membuat sebuah bahan ajar IPA berupa modul,dengan bentuk desain tata letak (layout) menarik, agar menumbuhkan rasa semangat ingin belajar siswa serta adanya edukasi tentang Covid-19 menggunakan pendekatan Sosio Saintific Issues (SSI). Karena hal tersebut dilakukanlah penelitian bertema "Pengembangan Modul IPA Berbasis Sosio Saintific Issues (SSI) Pada Materi Sistem Pernapasan Manusia Kelas VIII SMP".

\section{METODE}

Penelitian ini menggunakan penelitian Research and Development (R\&D) yaitu jenis penelitian yang digunakan untuk mengembangkan dan menguji barang baru. Analisis kebutuhan diperlukan untuk dapat mengembangkan produk tertentu, dan spesialis (media, bahan, dan bahasa) diperlukan untuk mengevaluasi kemanjuran produk sehingga dapat berfungsi di masyarakat luas. Penelitian dan pengembangan memiliki beberapa teori yang dapat di gunakan sebagai ancuan pengembangan, salah satu diantaranya teori Borg dan Gall yang dikemukanan oleh Sugiono (2016:298).

Penelitian pengembangan modul ini dilakukan di Sekolah Menengah Pertama (SMP) Bengkulu Tengah, yaitu SMPN 11 Bengkulu Tengah. Pada penelitian ini dilaksanakan dari tahap persiapan hingga tahap pelaksanaan, dimulai awal bulan November 2020 sampai dengan bulan Maret 2021.

Proses pengembangan yang digunakan dalam penelitian ini didasarkan pada teori perkembangan Borg and Gall yang terdiri dari sepuluh fase. Dari 10 langkah tersebut akan dibatasi peneliti disederhanakan menjadi 8 tahap pengembangan, karena keterbatasan waktu penelitian dan biaya yang dikeluarkan dalam proses produksi masal bahan ajar modul. Langkah-langkah pengembangan sebagai berikut: 1) potensi dan masalah, 2) pengumpulan informasi, 3) desain produk\&produk awal, 4) validasi desain, 5) revisi desain, 6) uji coba produk kelompok kecil, 7) revisi produk, 8) produk akhir. 
Subjek pada penelitian ini guru dan peserta didik kelas VIII SMPN 11 Bengkulu Tengah dijadikan sebagai subjek uji kelayakan produk. Dosen IPA berperan sebagai validator, serta ahli materi, ahli media, dan ahli bahasa, dalam tim validasi (evaluasi) penelitian ini terhadap kelayakan instrumen dan mata pelajaran.

Instrumen pengumpulan data yang digunakan pada penelitian pengembangan modul IPA menggunakan tahap analisis kebutuhan, validasi ahli, uji coba produk kelompok kecil. Instrumen pengambilan data dilakukan dengan cara menganalisis bahan ajar yang terdiri dari buku, lks, dan modul yang ada di SMPN 11 Bengkulu Tengah.

Teknik pengumpulan data dilakukan dengan penyebaran angket validasi yang disusun dalam pembuatan modul pembelajaran sosiologi berbasis Socio Scientific Issues (SSI) untuk mendapatkan penilaian dari validator, yang bertujuan untuk menguji kelayakan oleh ahli media/ desain, ahli materi, ahli bahasa, dan kepraktisan pengguna. Pada teknik ini angket diolah secara penyajian persentase dengan menggunakan skala likert sebagai skala pengukuran. Skala likert merupakan metode penskalanaan pertanyaan sikap yang menggunakan distribusi respon sebagai dasar penentuan nilai skalanya. Skala likert digunakan untuk mengukur sikap, pendapat, dan persepsi seseorang atau sekelompok orang tentang fenomena sosial yang mempunyai gradasi dari sangat positif sampai sangat negatif (Sugiyono, 2015:165).

Teknik analisis data digunakan untuk menghitung data dari ahli media/desain, ahli materi, ahli bahasa, dan kepraktisan penggunaan IPA materi sistem pernapasan dengan rumus sebagai berikut:

$$
P=\frac{f}{N} \times 100 \%
$$

Keterangan :

$\mathrm{P}=$ Agka persentase data angket

$\mathrm{f}=$ jumlah skor yang diperoleh

$\mathrm{N}=$ Jumlah skor maksimum

\section{HASIL DAN PEMBAHASAN}

Penelusuran kebutuhan siswa dan guru digunakan untuk mengumpulkan data tentang interaksi pembelajaran, bahan ajar yang digunakan, tantangan yang dialami siswa dalam memahami materi kerangka pernapasan manusia, pengembangan kembali materi dan kebutuhan modul pembelajaran IPA. Ujian persyaratan ini menggunakan survei terhadap kebutuhan siswa dan guru termasuk pengajar mata pelajaran IPA di Kelas VIII dan siswa di kelas VIII di SMP Negeri 11 Bengkulu Tengah.

1. Hasil Tahap Studi Pendahuluan

Penelitian berangkat dari sebuah masalah yang ditemukan di lapangan (sekolah), untuk menemukan permasalahan tersebut di perlukan observasi awal dan studi pendahaluan untuk menemukan potensi masalah. Untuk menemukan potensi masalah tersebut maka peneliti melakukan studi pendahuluan kepada guru dan siswa di SMP Negeri 11 Bengkulu Tengah untuk mengetahui proses pembelajaran di lapangan dan kebutuhan akan bahan ajar. 
Berdasarkan penelusuran awal peneliti menemukan bahwa proses pembelajaran dilaksanakan secara daring, namun di beberapa waktu tertentu sekolah melakukan kegiatan belajarar tatap muka dengan sistem kelompok (sip). Proses pembelajaran daring menggunakan media Whatapp dan Google Classroom. Namun terdapat beberapa kendala dengan menggunakan media tersebut diantaranya, jaringan internet di wilayah tersebut lambat sehingga menyulitkan siswa belajar secara mandiri di rumah.

Buku cetak merupakan sumber belajar yang dimanfaatkan siswa dalam kegiatan belajarnya. setiap siswa mendapatkan satu buku cetak setiap mata pelajaran IPA. Tampilan buku yang sudah lusuh dan sebagian halaman telah hilang menyebabkan siswa tidak dapat belajar dengan maksimal. Hal ini dikarenakan penggunaan buku digunakan secara berulang-ulang. Terlebih setelah peneliti melakukan analisis kebutuhan siswa, mereka tidak tertarik pada bahan ajar buku cetak karena ilustrasi gambar yang kurang menarik dan materi sistempernapasan yang sulit di pahami siswa. Lantaran pada materi sistem pernapasan manusia terdapat organ pernapasan manusia, konsep tentang frekuensi dan voume pernapasan manusia serta penyakit pada sistem pernapasan manusia yang sulit dipahami siswa karena minimnya ilustrasi gambar.

Sebagai tindak lanjut permasalahan tersebut peneliti megembangkan produk bahan ajar berbasis Sosio Scientific Issues (SSI). Penelusuran awal peneliti menemukanbahwa belum adanya baham ajar berbasis Sosio Scientific Issues (SSI). Bahan ajar yang dimaksud adalah Modul Pembelajaran IPA berbasis Sosio Scientific Issues (SSI) Pada Materi Sistem Penapasan Manusia untuk Siswa Kelas VIII SMP. Melihat adanya permasalahan Covid-19 maka peneliti menambahkan materi tersebut ke dalam bahan ajar yang merupakan permasalahan sosial dan sains saat ini. oleh sebab itu pentingnya edukasi dan pecegahan penularan Virus Corona Desease (Covid-19) Selain itu peneliti juga mengembanggkanisi instruksional modul dengan presentasi tata letak yang menarik bagi siswa.

2. Hasil Tahap Perancangan dan Pengembangan Produk Awal

Setelah melakukan proses studi pendahuluan yang bertujuan untuk mengetahui pelaksanaan pembelajaran, masalah yang dihadapi siswa dan guru dalam kegiatan pembelajaran serta kebutuhan akan bahan ajar modul. Selanjutnya tahap perancangan dan pengembangan produk awal. Tahap perancangan meliputi komponen yang dibuat pada modul penbelajaran seperti: kompetensi dasar, indikator pembelajaran, dan materi yang akan di bahas yang berpatokan pada kurikulum 2013 yang tertera dalam silabus. Setelah merancang komponen modul yang akan digunakan maka proses selanjutnya melakukan proses pengembangan.

Tahap kemajuan menggunakan pendekatan isu-isu sosiologis (SSI), SSI adalah isu-isu sosial dan logis yang membingungkan dan dipertanyakan 
yang juga dapat diuraikan sebagai teknik yang berencana untuk menghidupkan pergantian peristiwa ilmiah, baik dan moral, serta perhatian pada koneksi. antara ilmu pengetahuan dan aktivitas publik. Sosiologis (SSI) tentang masalah sistem pernapasan manusia meliputi siswa dalam pembelajaran open door di sekolah dengan setting wilayah yang lebih luas. Jadi masalah sosio logis (SSI) adalah metodologi berbasis kasus dan pembelajaran berbasis pengaturan (Friedrichen dkk, 2017:75-87). Materi yang sudah didapat kemudian dikembangkan dengan penambahan materi tentang corona virus desease (Covid-19) karena merupakan permasalahan sosial dan sains saat ini sedang terjadi. Materi yang sudah dipadukan dengan SSI selanjutnya, dirancang sedemikian rupa agar penampilan layout (tata letak) menarik dengan langkah-langkah pengembangan meliputi, penentuan ukuran media kertas (A4), menentukan bahan kertas yang akan digunakan (Art Paper 120 gsm), menentukan Margins /Layout Guide (2 $\mathrm{cm}$ ) dan pemilihan warna dasar modul (Pallette). Setelah proses tersebut untuk mendukung layout pada mudul agar menarik maka pemilihan gambar dan Icon yang digunakan dalam modul harus bagus. Peneliti megunduh gambar di situs gamabar yaitu unplash.com, freepic. com dan Png Download.id. Gambar yang telah diunduh kemudian di olah kembali di aplikasi Photoshop. Setelah di olah kemudian dijadikan file jpg dan disatukan didalam documen aplikasi Microsoft Word. File sudah siap untuk di cetak utuk kemudian di uji kelayakan dan kepraktisan.

\section{Uji Kelayakan Modul}

Menampilkan materi isian sebagai sumber perspektif untuk memahami topik dan aturan latihan dalam siklus pembelajaran. Ada berbagai macam bahan ajar yang dapat digunakan oleh pengajar dan siswa dalam siklus pembelajaran. Salah satunya adalah modul. Modul adalah suatu jenis bahan ajar yang dikemas secara utuh dan terencana, di dalamnya berisi sekumpulan pertemuan belajar yang disusun dan dimaksudkan untuk membantu siswa mencapai tujuan belajar, sesuai dengan keterampilan yang akan dicapai. Modul berisi tujuan pembelajaran, materi pembelajaran dan penilaian pembelajaran (Ramadhana dkk, 2017:320). Pada penelitian ini Modul yang telah di rancang lalu di validasi oleh validator meliputi ahli materi, bahasa dan materi. tujuan validasi adalah guna mengukur kepantasan modul yang dilakukan inovasi sebelmu diaplikasikan pada pembelajaran. Penilaian kelayakan tersebut diantaranya struktur dan komponen produk modul.

Hasil kelayakan modul pembelajaran IPA berbasis Sosio Scientif Issues (SSI) untuk siswa kelas VIII SMP dengan menggunakan rumus Skala Linkert seperti gambar 1.

Berdasarkan penilaian validator tersebut maka modul yang dikembangakn peneliti dari segi bahasa 94,66\%, materi $91,7 \%$ dan media $97,7 \%$ sangat layak digunakan. Hal ini berdasarkan skala interpretasi penilaian kelayakan modul dengan skor $81 \leq \mathrm{P} \leq 100 \%$ akan tergolong 


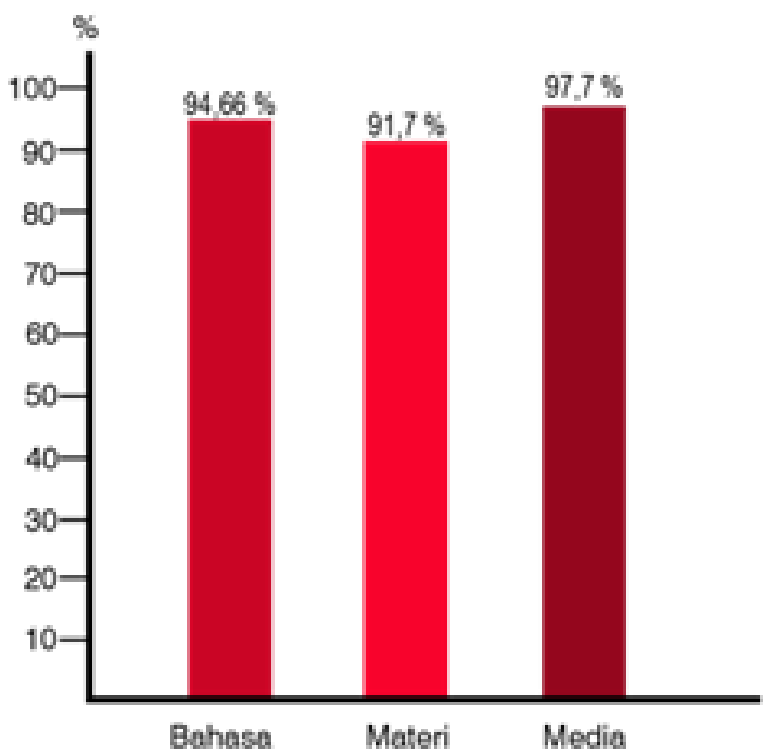

Gambar 1 HasilValidasi bahasa, materi dan media

bahan ajar sangat layak digunakan (Arikunto,2012:7). Dengan demikian berdasarkan Indikator kelayakan tersebut dikatakan valid dan sangat layak diterapkan, karena berada pada rentang $81 \leq \mathrm{P} \leq 100 \%$ Persentase tersebut menunjukan bahwa media yang dikembangkan dapat digunakan sesuai đengan revisi para ahli (Bitiningtias, 2016). Tujuan akhir dari uji kelayakan adalah untuk menyesuaikan produk pengembangan yang dibuat sejalan dengna kebutuhan dan keterampilan siswa dalam meningkatkan kebermanfaatan bahan ajar dalam proses pembelajaran.

4. Uji Kepraktisan Modul

Tahap uji kepraktisan dilakukan peneliti pada 10 orang siswa yang selanjutnya akan disebut responden dan 1 orang guru mata pelajaran IPA kelas VIII. Dari hasil penelitian yang dilakukan peneliti di SMP Negeri 11 Bengkulu Tengah responden siswa memiliki presentase $82,87 \%$ (sangat praktis), poin penilaian meliputi, desain cover, desain isi, penggunaan huruf, penyajian gambar, bahasa yang digunakan dalam modul, materi, tujuan pembelajaran, pemahaman siswa terhadap modul. Penilaian skor siswa disajikan melalui histogram pada gambar 2.

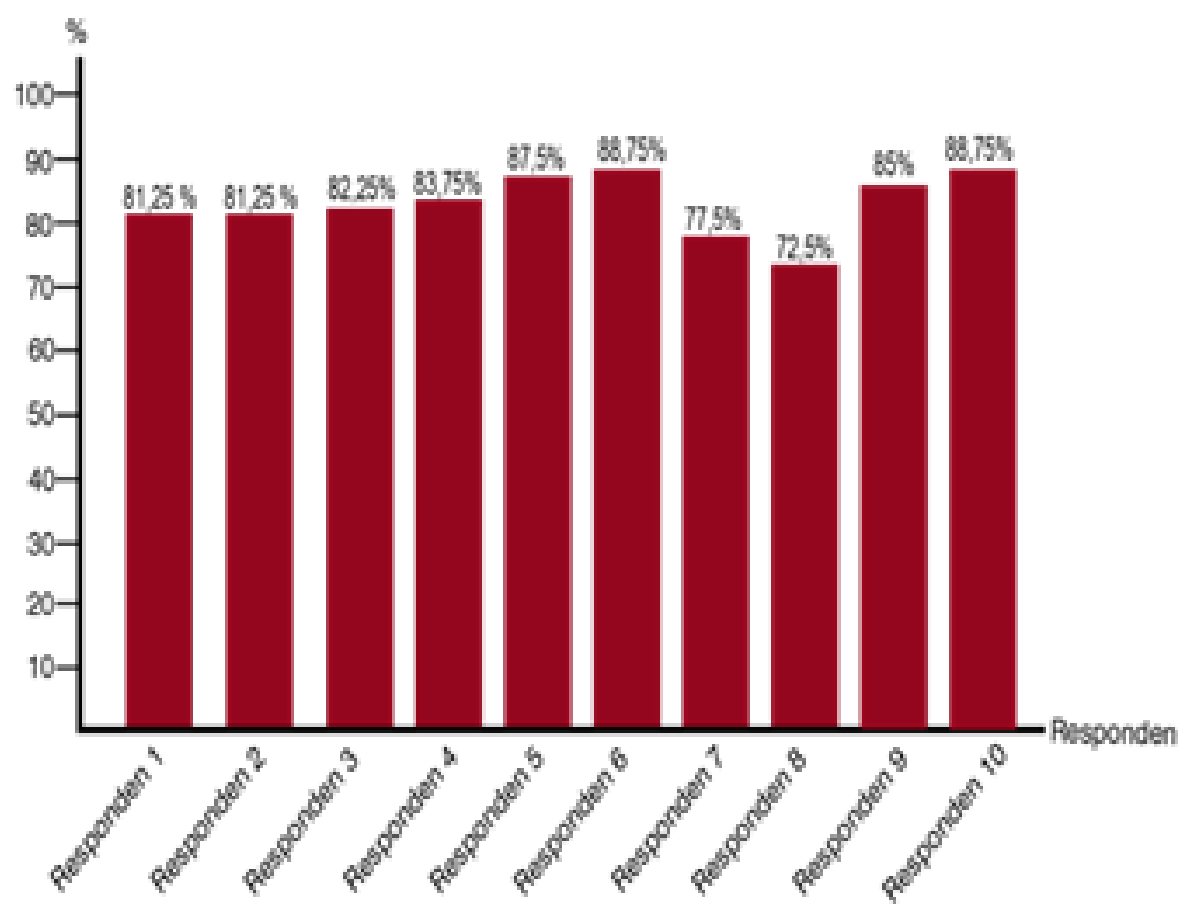

Gambar 2 Hasil Diagram Batang Responden 
Berdasarkan pada gambar 4.2 dapat dijelaskan bahwa responden 1 memiliki skor $81,25 \%$ (Sangat Praktis), responden 2 memiliki skor 81,25\%(Sangat Praktis), responden 3 memiliki skor 82,25\% (Sangat Praktis), responden 4 memiliki skor 83,75\% (Sangat Praktis), responden 5 memiliki skor 87,5\% (Sangat Praktis), responden 6 memiliki skor 88,75 (Sangat Praktis), responden 7 memiliki skor 77,5\% (Praktis), responden 8 memiliki skor $72,25 \%$ (praktis), responden 9 memiliki skor 85\% (Sangat Praktis) dan responden 10 memiliki skor 88,75\% (Sangat Praktis) rata-rata penilaian responden yaitu $82,87 \%$ dengan demikian berdasarkan analisis data mengunakan skala linkert berada pada katagori dengan rentang $81 \leq \mathrm{P} \leq 100 \%$ dan tergolong sangat praktis (Parmin, 2012:132).

Penilaian angket guru memiliki presentase $73,71 \%$ (praktis). Poin penilaian meliputi, cover modul, judul, tata letak,jenis huruf,gambar, kemenarikan, kemudahan memahami isi modul, petunjuk kegiatan, materi yang disajikan, sosio scientific issues, dan kegunaan modul dalam pembelajaran. Sebagai konsekuensi dari temuan ini, jawaban siswa dan guru menunjukkan bahwa modul sangat berguna dalam studi konten pencemaran lingkungan. Hasil dari data jawaban diperiksa, dan jika proporsi setuju lebih dari 61P81 persen, modul dianggap praktis (Pamungkas., dkk, 2017:270-278).

Uji kewajaran suatu modul sangat penting sebelum diterapkan dalam siklus pembelajaran, hal ini sesuai dengan penjelasan Nieveen yang menyatakan bahwa sifat butir-butir kemajuan harus pragmatis karena dalam media pembelajaran harus mudah dimanfaatkan oleh siswa sehingga dalam pembelajaran Siswa interaksi tidak mengalami kesulitan sehingga tujuan pembelajaran dapat tercapai sesuai tujuan normal (Annisa.,dkk, 2015:73).

\section{SIMPULAN}

Dari hasil penelitian, dapat disimpulkan bahwa uji kepraktisan modul dilakukan oleh tiga validator (spesialis), khususnya etimologis dengan taraf 94,66\% (umumnya sangat baik), ahli materi dengan taraf 91,7\% (mengagumkan), dan ahli media/rencana dengan taraf $97,7 \%$ (luar biasa). Dilihat dari hasil persetujuannya, maka dapat dikatakan bahwa soal yang dibuat seluruhnya praktis untuk digunakan dalam pembelajaran latihan soal siswa kelas VIII SMP.

Uji kepraktisan modul diselesaikan melalui penelitian skala terbatas di SMP Negeri 11 Bengkulu Tengah yang terdiri dari 10 siswa dan 1 pengajar mata pelajaran IPA KelasVIII. Hasil responden siswa terhadap bahan ajar modul dengan presentase 82,87 $\%$ (sangat praktis), hasil responden guru menunjukkan presntase 73,71 \% (praktis), berdasarkan hasil reponden guru dan siswa maka dapat disimpulkan modul yang dikembangkan memiliki katagori praktis untuk digunakan.

\section{DAFTAR PUSTAKA}

Annisa, Ayu Rizki. (2015). Kepraktisan Media Pembelajaran Daya Anti Bakteri Ekstrak Buah Sawo Berbasis 
Macromedia Flash. Jurnal Inovasi Pendidikan Sains 11(2), 73.

Arikunto, Suharsimi. (2012). Prosedur Penelitian. Jakarta: Rineka Cipta.

Auliya M., dan Nurmawati I. (2021) Pengembangan E-Modul Materi Pisces Kelas X SMA/MA dengan Konteks Potensi Pesisir Jembrana. Indonesian Journal of Mathematics and Natural Science Education. Vol 2 No 12021. Hal 45-51.

Bitiningtias, N. (2016). Pengembangan Pemainan Vormint Chemistry Sebagai Media Pembelajaran Pada Materi Sistem Periodik Unsur. UNESA Jurnal Of Chemical Education 5(2), 30.

Friedrichen P.J dkk. (2017). Evolution Of Model Sosio Scientific Issues Teaching and Learning. International Jurnal Of Education in Matematics, Science and Tecnology, 5(2), 78-87.

Galing,Wulung. (2013). LKP: Perancangan Desain Layout Media Interaktif PT. Berkah Sedaya (Doctoral dissertation, Stikom Surabaya).

Nurdyansyah, N. (2018). Pengembangan Bahan Ajar Modul Ilmu Pengetahuan Alam Bagi Siswa Kelas IV Sekolah Dasar. Universitas Muhammadiyah Sidoarjo.
Pamungkas Z, dkk. (2017). Kelayakan Modul Pembelajaran IPA Berbasis Potensi Lokal Pada Pokok Bahasan Perubahan Benda di SMPN 1 Semboro Kabupaten Jember. Jurnal Pembelajaran Fidsika 6(3), 270-278.

Parmin. (2012).Pengembangan Modul Pembelajaran IPA Terpadu Berwawasan Sains, Lingkungan Teknologi dan Masyarakat,Jurnal Penelitian Pendidikan 29(2), 132.

Ramadhana, Rizky. (2017).Pengembangan Modul Pembelajaran Berbasis Keterampilan Literasi.Jurnal Sekolah Tinggi Ilmu Pendidikan dan Keguruan YPUP Makassar,4(9), 316.

Sugiono. (2016). Metode Penelitian Kuantitatif, Kualitatif, dan R\&D. Bandung : Alfabeta.

\section{PROFIL SINGKAT}

Darmawan Setiadi Lahir Curup, 31 Desember 1996. Pendidikan terakhir Tadris Ilmu Pengetahuan Alam Universitas Islam Negeri Fatmawati Soekarno Bengkulu, tahun kelulusan 2021. Pekerjaan seharihari sebagai desainer grafis perusahaan swasta di Kota Bengkulu. 